\title{
Pemanfaatan Media Sosial Instagram Sebagai Ruang Diskusi Upaya Pencegahan Pelecehan Seksual di Lingkungan Akademis
}

\author{
*Wiwid Adiyanto \\ Universitas Amikom Yogyakarta \\ Jl. Ring Road Utara, Ngringin, Condongcatur, Kec. Depok, Sleman, Yogyakarta \\ *E-mail : wiwidadiyanto@amikom.ac.id
}

DOI: https://doi.org/10.21107/pangabdhi.v6i2.7594

Naskah diterima 18 Juni 2020, Revisi 30 Juli 2020, Terbit 29 Oktober 2020

\begin{abstract}
Abstrak
Pelecehan seksual bisa dialami oleh siapa saja dan di mana saja. Kampus yang seharusnya merupakan ruang publik yang aman, tidak lepas dari permasalahan pelecehan seksual. Pelecehan seksual di kampus tidak terlepas dari penyalahgunaan struktur kekuasaan, namun pelecehan seksual juga tidak menutup kemungkinan dilakukan oleh semua lapisan struktur yang ada di kampus. Permasalahannya adalah pelecehan seksual belum mendapat penanganan serius. Pengabdiam masyarakat ini bertujuan untuk memberikan sumbangsih edukasi terkait upaya pencegahan, perlawanan, literasi gender, dan juga perbaikan konstruksi sosial di masyarakat terkait pelecehan seksual. Pengabdian masyarakat ini dilakukan dalam bentuk virtual talk show yang bekerja sama dengan komunitas Feminis Yogya dan komunitas Perempuan Hari Ini. Hasil pencapaian dari virtual talk show ini terlihat bahwa audiens mengetahui bentuk-bentuk kekerasan seksual, memahami rantai dampak dari pelecehan seksual, mempunyai pengetahuan tentang konstruksi sosial dan budaya yang membentuk normalisasi keadaan, memiliki pengetahuan tentang cara mencegah pelecehan seksual di kampus, memiliki pengetahuan terkait hal yang harus dilakukan ketika mendapatkan pelecehan seksual di kampus, dan pemahaman feminisme yang merujuk pada kemanusiaan.
\end{abstract}

Kata Kunci : pelecehan seksual, kampus, konstruksi sosial, feminisme, literasi gender

\begin{abstract}
Sexual harassment can be experienced by anyone and anywhere. The campus which is supposed to be a safe public space, cannot be separated from the problem of sexual harassment. Sexual harassment on campus is inseparable from the abuse of power structures, but sexual harassment also does not rule out the possibility of being committed by all layers of structure on campus. The problem is sexual harassment has not yet received serious treatment. This community service aims to provide educational contributions related to prevention, resistance, gender literacy, and also improvement of social construction in the community related to sexual harassment. This community service is carried out in the form of a virtual talk show in collaboration with the Yogya Feminist community and the Women's Today community. The results of the achievement of this virtual talk show show that the audience knows the forms of sexual violence, understands the chain of impacts of sexual harassment, has knowledge about social and cultural construction that shapes the normalization of the situation, has knowledge about how to prevent sexual harassment on campus, has knowledge related to matters which must be done when getting sexual harassment on campus, and understanding feminism that refers to humanity.
\end{abstract}

Key Words: sexual harassment, campus, social construction, feminism, gender literacy

\section{PENDAHULUAN}

Permasalahan pelecehan seksual merupakan hal yang tidak mudah diungkap namun banyak yang mengalami, tidak terkecuali dalam lingkungan kampus. Pelecehan seksual bisa terjadi karena penyalahgunaan kekuasaan yang memposisikan pelaku berada pada relasi kuasa yang lebih tinggi hingga dirasa bisa memegang kendali dengan posisi superiornya (Dwiyanti, 2014).

Survei dari Lentera Sintas Indonesia dan Magdalene.co melalui Change.org menyatakan bahwa $93 \%$ orang yang pernah mengalami kekerasan seksual tidak melapor kepada pihak penegak hukum. Kampus merupakan tempat menimba ilmu tidak terlepas dari ancaman 
kekerasan seksual. Pengakuan dari penyintas yang dikutip dari portal pemberitaan Tirto.id menyatakan bahwa pelaku tindak kekerasan seksual dilakukan oleh beragam individu di kampus, mulai dari dosen, sesama mahasiswa, staf kampus, profesor, warga di lokasi KKN, bahkan dokter kampus (Zuhra, 2019). Safer Internet Forum (2019) merilis laporan bahwa pelecehan seksual bisa berujung pada pembunuhan yang berawal hanya dari candaan seksis.

Kasus pelecehan seksual di kampus yang terungkap juga banyak yang tidak kunjung menemukan penyelesaian yang dinilai adil bagi korban. Penanganannya pun dinilai lambat dan akses informasi dibatasi oleh institusi. Pembatasan tersebut dilakukan demi mempertahankan nama baik kampus. Kasus Mahasiswi inisial RW Fakultas Ilmu Budaya Universitas Indonesia yang dilecehkan oleh dosen belum menemukan penyelesaian yang jelas sampai saat ini. Selain itu ada Agni (bukan nama sebenarnya) mahasiswi Universitas Gadjah Mada yang kasusnya terpentok pada penyelesaian secara kekeluargaan atau damai. Tidak hanya itu, kasus pelecehn seksual juga pernah ditemukan di Universitas Negeri Jakarta atas pemerkosaan mahasiswi oleh dosen. Ada juga oknum dosen $\mathrm{ZH}$ dari Universitas Islam Negeri Maulana Malik Ibrahim Malang yang diduga melakukan pelecehan seksual pada mahasiswinya.

Tahun 2020, terdapat kasus pemerkosaan oleh FY yang merupakn oknum dosen di Universitas Negeri Padang kepada mahasiswinya. Alumnus Universitas Islam Indonesia Ibrahim Malik juga diduga sebagai predator seksual yang juga melakukan pelecehan pada mahasiswi di lingkungan kampusnya dulu. Kasus tersebut hanyalah segelintir kasus yang terpublikasi dimedia. Kejadian atas tindak kekerasan seksual di kampus masih banyak yang belum ditemukan.

Foucault (1978) menjelaskan bahwa kekuasaan ada di mana-mana. Begitu pula kampus yang merupakan tempat menimba ilmu tidak lepas dari kekuasaan yang ada di dalamnya. Hal yang paling terlihat adalah struktur yang diisi oleh orang-orang yang diberikan kekuasaan di dalamnya. Penyalahgunaan kekuasaan jelas menyalahi aturan. Lebih jauh lagi, tubuh adalah pertempuran antara pemangku kekuasaan yang menganggap dirinya dominan dengan yang dianggap lebih rendah (Foucault, 1980). Penyalahgunaan kekuasaan yang merujuk pada pelecehan seksual ataupun intimidasi seksual pada individu yang memiliki kuasa lebih rendah telah keluar dari nilai-nilai kemanusiaan.

Pelecehan seksual belum mendapat penanganan serius terutama dalam lingkungan akademis. Kurangnya pengetahuan masyarakat tentang upaya pencegahan dan penanganan kekeasan seksual di lingkungan akademis membuat kelompok Feminis Yogya dan penulis tergerak untuk membuat wadah diskusi terkait literasi penanggulangan permasalahan tersebut yang dibahas secara praktis dan teoritis di tengah pandemi Covid-19. Kegiatan ini berusaha menjangkau masyarakat luas, namun ada beberapa kondisi yang membuat perluasan jangkauan itu kurang maksimal. Feminis Yogya memiliki wadah edukasi melalui instagram, namun penggunaan fitur live Instagram belum dimanfaatkan secara maksimal. Pemanfaatan jaringan kelompok feminis di luar Yogyakarta juga dirasa belum maksimal.

Pemaparan di atas menunjukan beberpa permasalahan yang ada di masyarakat ataupun mitra, yaitu :

1. Pemanfaatan fitur live Instagram yang belum maksimal.

2. Rape culture yang masih ada di lingkungan akademis

3. Kurangnya pengetahuan terkait upaya pencegahan dan penanganan kekerasan seksual di lingkungan akademis secara praktis.

4. Kerja sama dengan jaringan kelompok feminis di luar kota Yogyakarta yang belum dimaksimalkan.

Kegiatan ini bertujuan untuk memberikan sumbangsih edukasi terkait upaya pencegahan, perlawanan, literasi gender, dan juga perbaikan konstruksi sosial di masyarakat terkait pelecehan seksual. Hal itu dilakukan dengan cara memberikan literasi tentang upaya pencegahan pelecehan seksual di kampus pada mitra dan masyarakat, memberikan literasi tentang bagaimana pilihan cara menyikapi saat mendapat pelecehan seksual di kampus, memberikan literasi terkait pola pikir yang berbasis kemanusiaan dengan unsur kesetaraan gender, dan mempererat jaringan antar kelompok feminis yang akhirnya bisa memperluas jangakauan edukasi terkait pembahasan gender. 


\section{METODE}

Pelaksanaan kegiatan ini dilakukan melalui fitur live Instagram pada akun mitra Feminis Yogya yang juga bekerja sama dengan akun Perempuan hari ini. Setidaknya ada 3 faktor pertimbangan untuk menggunakan fitur tersebut sebagai instrumen penyampaian pesan. Pertama, pelaksanaan kegiatan dilaksanakan saat wabah Covid-19 yang mengharuskan masyarakat menjaga jarak satu dengan yang lainnya, selain itu kesadaran bekerja, belajar, dan beribadah dari rumah sesuai anjuran pemerintah untuk memutus mata rantai virus. Kedua, dengan menggunakan media yang berbasis internet, jangkauan audien bisa lebih luas. Hal tersebut mengacu pada McQuail (2011) bahwa dengan keberadaan media berbasis internet yang melekat dalam kehidupan, konsep khalayak menjadi samar. Ketiga, aplikasi instagram merupakan aplikasi populer yang menyediakan fitur live.

Dengan kepopulerannya tersebut, aplikasi ini juga bisa disaksikan oleh siapapun pengguna aplikasi Instagram. Kegiatan ini memiliki tiga tahapan. Pertama adalah perencanaan, tahap kedua adalah pelaksanaan, dan tahap ketiga adalah luaran berupa penyamaan persepsi dan evaluasi. Virtual talk show ini dilaksanakan pada 8 Mei 2020 pukul 19.30 WIB sampai 21.30 WIB melalui akun Instagram Feminis Yogya dan akun Perempuan Hari Ini.

\section{HASIL DAN PEMBAHASAN Tahap Persiapan}

Pengusul melakukan pertemuan dengan pihak kelompok Feminis Yogya dan Kelompok Perempuan Hari Ini untuk merencanakan suatu kegiatan terkait literasi gender dan mengatasi kekerasan atau pelecehan seksual di lingkungan akademis. Kegiatan yang diputuskan adalah virtual talk show melalui fitur live Instagram yang disiarkan pada akun Feminis Yogya dan Perempuan Hari Ini. Penulis juga menjadi pemateri dalam virtual talk show yang diselenggaraan.

Promosi juga dilakukan sebelum kegiatan berlangsung melalui poster digital yang dipublikasi melalui akun Feminis Yogya dan Perempuan Hari Ini. Selain itu, poster juga dipublikasikan secara individu oleh sebagian besar anggota Feminis Yogya dan Perempuan Hari Ini.

\section{Tahap Pelaksanaan}

Pemateri memberikan literasi terkait upaya pencegahan pelecehan seksual dan juga langkah yang bisa dilakukan untuk mengupayakan tidak lanjut terkait pelecehan seksual yang terjadi, baik bagi pelaku maupun korban. Audiens dalam virtual talk show yang diselenggarakan mencapai 68 viewers yang terdiri dari pengikut akun Feminis Yogya di Yogyakarta, pengikut akun Perempuan Hari Ini di Medan, dan pengguna Instagram di luar kedua akun tersebut. Sebagaian besar audiens berasal dari kalangan mahasiswa dan mahasiswi. Tingkat literasi gender baik dari Akun Feminis Yogya dan Perempuan Hari ini sudah baik, begitu juga literasi audiens yang mengikuti virtual talk show yang diselenggarakan. Permasalahannya adalah, kurangnya pengetahuan akses atau wadah untuk mengadukan pelecehan seksual yang masih dianggap remeh bagi beberapa institusi pendidikan. Oleh karena itu, penjelasan akses ke Lembaga Bantuan Hukum yang ada di kota Yogyakarta dan Medan diberikan sebagai salah satu upaya perjuangan pemberantasan pelecehan seksual dalam lingkungan akademis. Selain itu, audiens juga diperkenalkan dengan kelompok atau organisasi kesetaraan gender yang bisa menjadi tempat sharing yang pada akhirnya menjadi wadah atau sarana perjuangan melawan pelecehan dan kekerasan seksual melalui berbagai cara.

Penjelasan mengenai cara perlawanan juga disampaikan secara sederhana. Penanggulangan kekerasan seksual dibagi menjadi 2 cakupan, yaitu hal yang bisa dilakukan untuk jangka panjang dan hal yang dilakukan untuk jangka pendek maupun spontanitas. Hal yang bisa dilakuakan jangka panjang adalah merubah pola pikir masyarakat terkait konstruksi dominan lakilaki dan perempuan. Perubahan tersebut dilakukan dengan counter wacana dominan melalui berbagai macam hal. Mahasiswa dan mahasiswi merupakan akademisi. Dalam lingkup akademis, penelitian terkait permasalahan gender maupun pelecehan dan kekerasan seksual menjadi hal yang sangat dianjurkan untuk dilakukan oleh audiens. Pemateri juga membuka ruang konsultasi bagi audiens yang tertarik menulis penelitian atau artikel ilmiah tentang permasalahan gender. Hal itu dilakukan karena konstruksi sosial dominan terkait gender merupakan kebenaran yang seolah menjadi sesuatu yang "given".

Konstruksi sosial berasal dari pengetahuan yang dibenarkan oleh mayoritas masyarakat yang biasanya menjadi kebenaran tunggal. 
Pengetahuan itu didapat dari penelitian dan pengamatan, yang artinya pengetahuan bisa dikritisi atau diperdebatkan kebenarannya. Maka dari itu peran penelitian sangat penting untuk mengubah wacana. Penelitian yang dapat dipertanggung jawabkan bisa digunakan sebagai dasar kebenaran lain selain kebenaran nilai dominan. Selain itu hal yang bisa dilakukan untuk merubah wacana kesetaraan gender adalah sosialisasi word of mouth. Beberapa audiens belum memahami secara mendalam mengenai kesetaraan gender dan dampak kesetaraan gender untuk mereduksi kekerasan dan pelecehan seksual. Beberapa diantaranya belum memahami terkait bentuk- bentuk kekerasan maupun pelecehan seksual. Dengan adanya literasi gender yang di dalamnya juga terkait pembahasan pelecehan dan kekerasan seksual, audiens bisa melakukan sosialisasi lanjutan pada lingkungannya. Dengan begitu, diharapkan terbentuk efek bola salju yang akhirnya pelecehan seksual, kekerasan seksual, dan juga diskriminasi pada perempuan bisa diminimalisir secara bertahap.

Hal berikutnya adalah mendorong kampus yang belum memiliki wadah pengaduan pelecehan seksual untuk membuat bagian khusus yang menangani permasalahan tersebut. Ini bisa dilakukan dengan menyampaikan aspirasi melalui kerja sama dengan Badan Eksekutif Mahasiswa, Senat kampus, ataupun secara personal dengan pihak penentu kebijakan di kampus. Wadah pengaduan ini diharapkan juga melakukan pendampingan pada korban kekerasan seksual dan menjadi tim yang menyelidiki kebenaran dari suatu kasus. Alasan utama untuk membentuk bagaian konseling kekerasan seksual di kampus bila belum ditemukan kasus kekerasan atau pelecehan seksual di kampus adalah, mencegah lebih baik daripada memperbaiki. Hal itu ditujukan agar lingkungan akademis berjalan menuju kampus yang bersih dari kekerasan seksual yang didasari oleh kesadaran tiap individunya.

Hal yang bisa dilakukan secara langsung atau hal yang bisa dilakukan dalam jangka pendek adalah melapor bila melihat atau menjadi korban pelecehan seksual di lingkungan kampus. Permasalahan yang dikeluhkan audiens adalah kurangnya wadah pengaduan terkait pelecehan seksual yang dilakukan oleh oknum dosen, staf, maupun teman sendiri yang berada di kampus. Tidak semua kampus menyediakan konseling atau pendampingan internal terhadap korban kekerasan seksual yang terjadi di kampus. Kondisi teresebut membuat audiens merasa hanya memiliki 2 pilihan, yang pertama yaitu melapor keluar kampus seperti lembaga bantuan hukum maupun sharing pada komunitas yang memungkinkan untuk mendapatkan pendampingan, dan yang kedua adalah diam. Audiens menyatakan cenderung diam diawal saat menjadi korban kekerasan atau pelecehan seksual. Seiring berjalanannya waktu beberapa audiens baru mulai terbuka atau memberanikan diri sharing ada komunitas kesetaraan gender yang dia temui. Hal tersebut membuat isu kekerasan seksual mendapatkan perlawanan dari luar kampus ke dalam kampus. Pada akhirnya terjadilah suatu konflik dengan tema keadilan dan nama baik kampus.

Pemateri memberikan upaya yang bisa dilakukan untuk memerangi pelecehan seksual yang terjadi di kampus secara internal. Yang pertama adalah dengan menegur oknum tersebut secara personal dengan tenang, karena bisa jadi oknum yang melakukannya tidak mengerti bahwa apa yang dia lakukan merupakan bentuk dari pelecehan. Cara ini dilakukan dengan memperhatikan tingkatan pelecehan seksual yang dilakukan oleh oknum tersebut. Bisa juga dengan memberi teguran keras bila pelecehan yang ditemui dirasa sangat mengganggu. Bila sampai pada tingkat kekerasan atau percobaan pemerkosaan, tentu saja korban harus berusaha sekuat tenaga untuk melawan dan tetap tenang. Pikiran yang tenang sangat diperlukan agar tetap sadar dan tidak terjadi tonic immobility. Tonic immobility adalah keadaan yang membuat badan seakan lumpuh sementara dan sulit melakukan penyerangan dikarenakan panik dan shock. Perempuan yang dirasa paling rentan menjadi korban kekerasan lebih berpotensi mengalami tonic immobility, apalagi bila tidak dibekali dengan pengetahuan bela diri saat menghadapi kekerasan seksual. Untuk meminimalisir permasalahan tersebut Feminis Yogya mengadakan kelas women self defense, yaitu kelas bela diri yang membekali perempuan untuk melawan bila mendapat perilaku kekerasan seksual.

Kedua, bila belum ada wadah khusus penanganan kekerasan seksual di kampus, laporkan pada orang yang menjadi atasannya secara struktur. Pelaporan tersebut dengan catatan, kerahasiaan identitas pelapor harus dilindungi. Hal itu bisa diupayakan dengan komunikasi pada pihak terkait. Pelaporan pada 
atasan merupakan upaya penindaklanjutan kasus pelecehan seksual dalam internal institusi kampus. Pelaporan dan penindakan ini sangat penting bagi kedua belah pihak, baik bagi korban maupun kampus bila dilakukan dengan tegas dan adil. Audiens juga diliterasi dengan tidak menyalahkan diri sendiri bila dirinya yakin bahwa dirinya tidak salah. Minimal tidak menyalahkan diri sendiri di awal saat mereka menjadi korban. Hal ini menanamkan audiens bahwa dalam kejadian kekerasan seksual, korban adalah pihak yang tidak bersalah. Pihak yang bersalah adalah pelaku.

Pemateri menyampaikan pemaknaan hak pada audiens dengan mengutip dari Kusuma dan Tim dengan bukunya Melawan Kekerasan Seksual di Lingkungan Pendidikan. Hak merupakan semua yang didapat oleh setiap individu yang sudah ada dari lahir, bahkan sebelum individu masih dalam kandungan. Setidaknya ada tiga hak korban kekerasan seksual. Pertama adalah hak penanganan, korban memiliki hak untuk dilakukan penanganan lebih lanjut atas kejadian yang menimpanya. Aparat penegak hukum ataupun pihak yang berwenang wajib menindaklanjuti kasus yang menimpa korban. Hal itu juga termasuk hak atas informasi kekerasan seksual dan penanganannya, hak pendampingan hukum hak atas penguatan psikologis, dan hak atas pelayanan kesehatan.

Kedua adalah Hak atas perlindungan. Hak yang kedua ini termasuk hak atas informasi dan penyelenggaraan perlindungan, hak perlindungan dari ancaman dan kekerasan pelaku, hak kerahasiaan indentitas, dan hak perlindungan dari aparat penegak hukum yang justru merendahkan korban. Ketiga adalah hak atas pemulihan. Hak tersebut mecakup hak pemulihan fisik, psikis, dan hak ganti rugi (Kusuma, Nafi, Veronica, Setiawati, \& Nafi, 2020). Pengetahuan audiens terkait hak yang berhubungan dengan kekerasan seksual pun bertambah. Dengan begitu literasi terkait kekerasan seksual pun bisa lebih bermanfaat bagi audiens.

Aturan dan wadah pengaduan terkait kekersan seksual sangat diperlukan pada lingkungan akademis. Aturan tersebut juga harus dipatuhi oleh setiap individu yang ada di dalamnya. Dalam aturan tersebut juga harus terbangun pemantauan, baik dari pihak pimpinan kampus ke seluruh anggotanya atau dalam struktur vertikal, maupun pada jejeran struktur secara horizontal. Walaupun demikian, memaksa korban secara langsung untuk menceritakan kejadian yang dialaminya juga merupakan tindakan yang tidak boleh dilakukan. Hal itu dapat menambah trauma korban terkait kejadian tersebut.

Pencegahan kekerasan seksual akan lebih efektif bila tiap individu saling bekerja sama untuk memeranginya. Salah satu caranya adalah menanamkan budaya kemanusiaan pada tiap-tiap individu yang juga diterapkan dalam lingkungan akademis. Fungsi pengawasan antara individu satu dengan yang lainnya hanyalah upaya untuk mereduksi atau mencegah secara peran indivudu yang taat aturan terkait kekerasan seksual. Namun yang jauh lebih diperlukan adalah kesadaran akan memanusiakan manusia itu sendiri.

Pembahasan tentang studi Feminisme juga disampaikan dan dibahas kepada audiens. Studi tentang feminisme disampaikan secara sederhana dan langsung pada esensinya. Studi feminisme adalah ilmu yang mempelajari tentang perjuangan kaum perempuan untuk memperoleh kesetaraan gender. Esensinya adalah kesetaraan pada setiap manusia terlepas dari apapun jenis kelamin dan rasnya. Permasalahan yang terjadi terkait feminisme adalah citra feminisme yang keras, memberontak, serta penuh perlawanan dengan teriakan. Kesan urakan dan melawan kodrat adalah permasalahan utama yang harus rekonstruksi.

Beberapa audiens juga memaknai menjadi feminis dengan harus ikut turun ke jalan dengan berbagai aksi. Mengikuti aksi turun ke jalan di hari perempuan, hari buruh, Women March, dan lainnya dimaknai sebagai syarat utama menjadi feminis dan menunjukan solidaritas atau feminisme dimaknai dengan bergaya maskulin dan berbicara kasar. Tidak ada yang salah mengikuti aksi turun ke jalan selama itu dilakukan dengan tertib. Melakukan aksi juga tidak menjadi masalah jika itu dilakukan atas solidaritas kemanusiaan tanpa mengesampingkan kemanusiaan individu atau golongan lainnya. Hal yang terpenting dalam feminisme adalah bagaimana kesadaran dari setiap orang yang memahaminya. Hal tersebut diliterasi dengan menyampaikan esensi feminisme, yaitu kesetaraan yang berdampingan dengan damai tanpa ada diskriminasi. Feminisme bukan gerakan yang berbalik merendahkan laki-laki. Menjadi feminis tidak hanya bisa dilakukan oleh perempuan, namun menjadi feminis bisa dilakukan oleh laki-laki. Berikut foto dari virtual talk show yang disiarkan melalui fitur live 
Instagram Feminis Yogya dan Perempuan Hari Ini yang diselenggarakan :
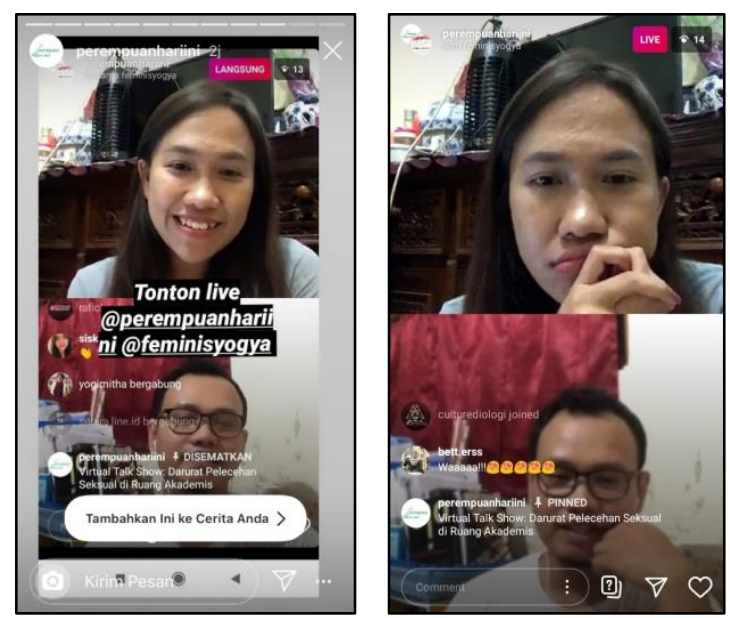

Gambar 1. Pelaksanaan Virtual Talk Show

\section{KESIMPULAN}

Waktu diskusi yang diadakan memberikan kesempatan audiens untuk aktif memberikan pertanyaan ataupun komentar yang didiskusikan. Dari diskusi yang berlangsung, audiens merespon dengan pemahaman yang lebih baik mengenai konsep studi feminisme. Pengetahuan audiens terkait upaya yang harus dilakukan sebagai mahasiswa untuk mencegah dan menindak lanjuti pelecehan seksual juga bertambah.

Perubahan memang tidak dirasakan langsung, perlu kegiatan lanjutan untuk terus memupuk kesadaran masyarakat terkait konstruksi dominan yang sering menaturalisasikan pelecehan seksual. Audiens juga bisa melakukan diskusi ataupun sharing terkait kesetaraan gender dan kasus pelecehan seksual pada pemateri di luar kegiatan sebagai tindak lanjut dari virtual talk show ini. Kegiatan ini secara tidak langsung melakukan sosialisasi pentingnya bela diri termasuk perempuan untuk mengantisipasi kekerasan seksual yang datang.

\section{DAFTAR PUSTAKA}

Dwiyanti, F. 2014. Pelecehan Sekual Pada Perempuan di Tempat Kerja (Studi Kasus Kantor Satpol PP Provinsi DKI Jakarta. Jurnal Kriminologi Indonesia. Vol 10(1), 29-36 pp.

Foucault, M. 1978. The History of Sexuality Volume 1: An Introduction. New York: Pantheon Books.

Foucault, M. (1980). Power/Knowledge: Selected Interviews and Other Writings 1972-1977. New York: Pantheon Books.

Kusuma, I., Nafi, Y. K. D., Veronica, Stiawati, D., \& Nafi, T. H. 2020. Melawan Kekerasan Seksual di Lingkungan Pendidikan. Jakarta: Yayasan Pustaka Obor Indonesia.

McQuail, D. (2011). Teori Komunikasi Massa (Edisi $6 \mathrm{Bu}$ ). Jakarta: Salemba Humanika.

Safer Internet Forum. (2019). From Online Violance to Digital Respect. Brussels.

Zuhra, W. U. N. (2019). Testimoni Kekerasan Seksual: 174 Penyintas, 79 Kampus, 29 Kota. Retrieved from Tirto.id website: https://tirto.id/testimoni-kekerasan-seksual174-penyintas-79-kampus-29-kota-dmT. 
2 Jurnal Pangabdhi 